DOI : $10.14746 / \mathrm{pp} .2015 .20 .4 .12$

Clifford A. BATES, Jr.

Warsaw University

\title{
Contemporary Comparative Politics and Revival of Regime Analysis Contra Reviving Aristotle's Regime Science*
}

\begin{abstract}
This paper suggests that upon comparing the various behavioural models and post-behavioural approaches (mostly understood as "the return of the state" and the concept of the political regime that emerges from that return) to compare political systems, we discover that Aristotle's science of regimes is a superior framework to various models advanced by the majority of regime frameworks of contemporary comparative political science. In examining that whole attempt to recover the regime as a means to analyze human political behaviour one finally comes to see that Aristotle's approach allows a more accurate and precise presentation of human political behaviour found within the structure of given political communities that are shaped by the given form of a particular regime.
\end{abstract}

Key words: Aristotle's politics, comparative politics, regime(s), political system(s), behaviouralism

W hen looking at the attempts by major voices of comparative political science to not only give a model to analyse the political phenomena of the state but how to compare different institutional expressions of the state, we can say there has been little improvement from Aristotle's teaching about the regime (politeia) found in his Politics. After nearly a century attempting to replace the model of political science that emerged in the $18^{\text {th }}$ and $19^{\text {th }}$ centuries, that emerged out of early modern political thinkers (e.g., Hobbes, Locke, Tocqueville, etc.) with new approaches, models and frameworks that are said to be "current", "up to date", and/or "scientific", this "revolution' only led to a greater forgetting, and dismissal as well, of the earlier frameworks both the older Aristotelian tradition and the "New Science of Politics" introduced by the early Moderns. Now, the political science created by the "Behavioural Revolution" and the various frameworks that emerged from it all too often had built-in, and unaddressed bias - that is to say it all too often used models and typologies that relied on concepts or variables that often reflected undefended values or goods that loaded the concept or variable to favour certain political forms or goods over others. Also the models and framework that emerged out the "Behavioural Revolution" often were charged by the critics that they were not truly able to address political phenomena on its own terms and thus they distorted what they were attempting to explain and analyse.

This paper will review the final steps that led contemporary political science to once again come to see the question of the form of the political community as the key to allow one an accurate and effective means to more precisely model and measure human politi-

*Artykuł został napisany w ramach projektu badawczego "Podstawowa literatura przedmiotu a kształt współczesnej politologii. Political science, Politische Wissenschaft i politologija w ujęciu porównawczym" (2012/05/B/HS5/00597), finansowanego przez Narodowe Centrum Nauki. 
cal activity initially. At first, contemporary political science broke away from the view of the state held by early modern political thinkers (such as Hobbes, Locke, Rousseau, Kant, Hegel, and others) and embraced what was understood as the behavioural revolution in the social sciences, and upon becoming increasingly dissatisfied with that approach, returned once again to the concept of the state.

With the so called "return to the state" and the attempt to find effective models to allow the effective comparative analysis of states, a reinvention of "regimes" occurred. Yet when evaluating the various contemporary regime models one comes to discover that all of them have built in bias favouring one form of political regime over another - something the creators of these new models either ignore or embrace. And if we then contrast these contemporary regime models to Aristotle's science of politeia, we discover that Aristotle's approach is not only superior to the various contemporary models of regime analysis in terms of avoiding internal bias effecting evaluations, but also Aristotle's approach is much more respectful of the complexity of human beings as social animals whose social nature operates within the context of human biology per se, the different environmental setting of which those human animals live and reproduce over time, and the institutions and structures those human social animals create to help them not only fulfil their social natures but also help them live well and beautifully.

\section{Contemporary Political Science Attempts at Reinventing the Political}

Contemporary political science, starting with the behavioural revolution in America from the 1930 s on, and the political development that the understanding of the state and the political behaviour of actors that give form to the state and its environment is vastly different from the state that emerged from the political thought of the early modern political thinkers such as Hobbes, Locke, etc. The view of politics as a unifying 'will' was thought to leave out or fail to address things that had a much greater impact on the political behaviour of humans beings than the formal administrative institutionalism that followed from this understanding of the state as the sole and fundamental political actor. It is linked with the reaction of the voluntarism and willing state by late moderns who turn hostile to the teaching of the early moderns as way too anthropomorphic and too metaphysical, attributing to social and political units the characteristics of living organisms. Again this is very much the case of the leading voices shaping the behavioural revolution, such as Lasswell and Merrian, who are all but names from the past that new generations of political scientists often have little knowledge of. Also the scientific pretensions of later moderns and their materialism and reductionism led to a reaction against the willing agency of the modern Hobbesian state which can be seen in much of the writing of the great sociological scholarship of the late nineteenth and early twentieth centuries. Such scholarship stressed that it was the various impersonal forces of mass society acting and interacting with each other though the various institutional structures that historically emerged in each given socio-ethnic grouping, which produced the given outcomes that we call politics. All of this was very far, not only from the state teaching of Hobbes et al., but also far more reductionist than Aristotle's political teaching. 


\section{The Birth of Behavioural Comparative Politics and the Political System}

Even if we go back to the origins of contemporary comparative political science scholarship, arising from the behavioural tradition (e.g., Lasswell and Merrian) of political science, which saw itself as a clear breaking away from more historical/descriptive and legal/institutional traditions of political science, one cannot simply say regime analysis was not a concern. One could argue that Almond's construction of the political system combining David Easton's rational-analytical model of a function system and the structural-functionalist approach of Talcott Parsons et al. found in sociology scholarship of the same period was in fact a form of regime analysis.

One sees clearly that what Almond thought his approach to the comparative political system was could be seen as following in Aristotle's "empirical" footsteps, although going far beyond what Aristotle could have achieved, due to Aristotle's limited experience and the changes in our knowledge of politics due to historical events that Aristotle was simply unaware of and could hardly be expected to either know or deal with. Yet if one looks at the Almond comparative political system model all too many later students of comparative politics found it very unsatisfactory, in that they found that it reduced too many complex and nuanced socio-political phenomena into an overly abstract model.

David Easton's systems analysis approach is a conceptual model showing the universal frame of political systems. The systems approach gives a conceptual framework that allows comparative politics to have a very systematic and rigorous method of comparing differing countries, that is it (the systems approach) provides an analytical knife to allow us to examine the parts of a political system and see how they interact. The universality of this approach allows the scholars of comparative politics to view how "variables relate to each other, from one system to another." In plain language, Easton's systems analysis is nothing more than the general bone structure of political bodies, showing the dynamic nature of political systems. This approach is useful in examining all political systems: from authoritarian to pluralist, and from "so-called" primitive societies to highly industrial-technological ones. However, one is forewarned, that systems analysis, as Easton notes, is not an empirical theory. He says his approach does not "provide causal relationships that predict and explain political behaviour. Hence, its use is limited to analysis."

Easton's systems analysis is not free from problems. The critics charge that it overemphasises equilibrium, status-quo, and persistence. Another criticism is that his approach does not take into account the "great man" theory of politics. That has the bias of the liberal paradigm. These criticisms are valid but tend to underrate the universality of the system approach (its specific comparative nature). However, some of the gaps (holes) that are in the systems approach (such as what the inner workings of "inputs" and "demands" are) do leave it open to valid criticism. This is where structural functionalism comes in.

Structural functionalism is an improvement on Easton's system analysis approach. Almond, in his development of structural functionalism is working within Easton's system framework. This approach fills most, if not all, the conceptual "holes" that were mentioned above in the "raw" systems approach. The inner working of the structural-functionalist approach is derived from Talcott Parsons and developments of sociology in the early 1950s. It tends to look at the inner-relations between government and society, (i.e.: explain government action in terms of societal interaction versus governmental auton- 
omy). Because of its inclination to weigh in societal factors, some critics claim it is very deterministic. That criticism is only valid in reference to how the "structural functionalistic" approach is being used to explain political phenomena. If it is used deterministically, then blame the scholar using it rather than the approach itself. This approach appears to be deterministic because of its very descriptive, analytical and rationalistic method. However, sciences that employ such methods (such as economics and sociology) are often criticised as being deterministic.

In his essay, "Toward a Non-ethnocentric Theory of Development" (1985), Wiarda criticises definitions of political development, like Almond and Verba, as having an implicit Western ethnocentric bias. He argues that the Westernised definition of what composes "Good Society" should not be the method of measuring the political development of non-Western nations or societies. Thus the frame that behaviouralists and scholars like Huntington use to understand political development is very much akin to the same types of models they understand the political systems of those non-western states to have. Wiarda continues that the method of measuring development should come from within the particular culture being examined. Here he is very much echoing the position of Clifford Geertz, whose hostility to any comparative methods to understand the alien other is well known. Following Geertz, Wiarda argues that each society shall be judged from its own set of goals as to whether that nation is "developed" or not. Wiarda argues that ethnocentrism creeps in no matter what. This is shown in that

[Gabriel] Almond's original functional categories were reasonable and non ethnocentric enough, but in actual practice "rule adjudication" was taken to mean an independent judiciary, political parties and an independent legislature were required, and countries that lacked these institutions were too often labelled "dysfunctional" (Wiarda, 1991, p. 37).

Thus Wiarda's criticism of the models of development very much echoes the problem of looking at the way that behaviouralists, such as Almond and Dahl, try to categorise in a systemic fashion. All too often one of the factors that shape the system of categorisation implicitly or explicitly favour liberal democracy in one fashion or another.

When one looks at the models of the political system that emerge from the scholarship of Almond and Dahl in this mid-period of the "Behavioural Revolution" in the late 50s and 60s, one can see an attempt to re-do some model or typology of political systems that was similar to what Aristotle did. All too often, scholars like Almond and Dahl would make noises about Aristotle's discussion about regimes as being very interesting and suggestive and something students of comparative politics should pay attention to, yet at the same time openly remark that Aristotle's approach is overly simple or outdated, and that more modern voices such as Weber and/or Lasswell should be relied on more. This is seen by Dahl's criticism in his 1964 classic Modern Political Analysis, where he openly and explicitly states that Aristotle's approach to politics leaves out too many important things that any true study of politics must take into account. Yes this contradicts what Dahl (and others like Almond, Powell and many of the generation of behavioural political scientists) remarked with wonder and surprise about the "gems" of insight that can be found in Aristotle about the very complex character of political change that remains valuable even today.

Although in this part of the paper I have focused on 'behavioural' comparative political scientists such as Dahl, Verba, and Almond and their regime modelling, if one turned 
to what Samuel Huntington does in his 1968 classic Political Order and Changing Societies one sees similar reliance on Aristotle and what other classical thinkers of politics had to teach on the question of how to understand the relationship between what gives shape to a given political order and how change occurs in such a political order (Huntington, 1968 , p. $25,56,80-81,178$ ). It is this work of Huntington, rather than his more popular and more citied work on the "Clash of Civilisations," that is held to be his "most powerful, original and theoretical work, and his most enduringly influential in the academic literature" (Lowenthal, 2009).

Huntington's model of political orders is strikingly similar to Aristotle's original twofold regime model that is traditionally held to be Aristotle's teaching about regimes. If one looks at Huntington's typological order for the various types/categories of political order we see something that brings to mind immediately Aristotle's well known two-fold typology of regimes (the one that produces the classic six form of political regimes/constitutions) (see Huntington, 1968, p. 80).

In lieu of Aristotle's categories of quantitative number of those ruling (what I call the quantitative claim) and what I call the qualitative claim (rule either for the interest of the ruler, or that of common advantage of ruler and ruled), Huntington substitutes the level of 'participation' (with three categories of low, medium and high) for the number of those ruling (one, few and many) and the 'ratio of institutionalisation to participation' (with two categories high-civic or law-'praetorian') for the difference between self-interested rule by ruler or rule for the common advantage (Huntington, 1968, p. 80).

As we turn to this criticism of Aristotle levelled by Dahl in his 1962 classic (as well as criticism by Almond and others) we see that much of this problem arises from taking as the final teaching the twofold regime model of Politics 3.7. We will show that this tendency by all too many readers of Aristotle to take the regime typology of Politics 3.7 as the definitive teaching and the view that the practical teaching is a blurred confusion that although useful and very insightful cannot possibly derive from what one gets in Politics 3.7. The argument I shall put forward is that this inability to see how Aristotle's regime science is a complete and coherent whole, and not the incoherent and fragmented thing that the "Founders" of Comparative Politics claim it to be, is the failure to read carefully and work out the dialectic argument that the text of the Politics offers the reader, and not the simple textbook that modern readers expect the Politics to be.

\section{Early Reactions against the Behaviouralist Comparative Politics Model}

Another criticism of many scholars of the post-1960s/70s reaction against the behavioural approach to the Almond model was its apparent built-in bias, subsuming most if not all of the assumptions of the pluralist model of Robert Dahl, which in its very form of modelling posits the goods of democratic values while openly claiming to be offering a value-free and objective political science that avoids the normativism that is all too often found in the tradition of political science that came before the Behavioural Revolution in political science.

One of the leading critics of the behaviouralist approach to comparative politics was the leading British scholar of politics Samuel Finer. Finer is little remembered in US cir- 
cles, but in the UK he is seen as one of the bigwigs who shaped comparative politics. It was under Finer's leadership in the politics department of Manchester University in the 1960s that helped established that department's later reputation as one of the leading centres for the study of politics in the UK. He later became Gladstone Professor of Government and Administration at the University of Oxford and remained there until his retirement in 1982. It was in retirement that he worked on his multivolume History of Government, which was only published after his death. Finer presents there his own regime typology, one resting on a twofold typology of what Finer labels (1) the 'palace' versus 'forum' - dealing with where political decisions are formed, shaped, made and executed and (2) the 'church' versus 'nobles' - which takes into how elites are to be shaped (inclusive of rule by those holding power out of or from modern ideological commitment/belief) versus those who hold power due to noble status (Finer, 1997).

Clifford Geertz, who is considered one of the most important scholars in Area Studies - a significant sub-field in comparative politics, rejects the notion that there exists a universal human nature that can explain human social behaviour. He argues that culture, which is created, varied, diverse and relative, is what defines what a human being is and how he or she will behave socially (see Geertz, 1973 and 1965). Geertz's approach was highly descriptive in character and it tended to echo more traditional historical approaches that sought to describe in great detail the political institutions and structures of the non-Western country that one was trying to understand. By replacing universal and objective measures with culturally "relative" measures, one would ultimately make comparison impossible (see Geertz, 1973). If we cannot compare in a non-relativistic way, then comparative political science is not at all useful in helping us understand societies we wish to examine.

\section{The "Return to the State"}

The system approach and structural-functionalism tend to place a great deal of emphasis on the inputs that the environment has on "government" in their examination of politics. This "environmental" framework of the above approach, critics charge, confuses politics with those environmental (i.e.: societal) factors. The critics desired an approach to the study of politics that attempts to look at that which is specifically political. Hence, the renewed interest in the "state" as an analytical concept in the field of comparative politics. This renewed interest has been labelled as the return of the state. This return to the study of "the state" (as typified by authors such as Nettl, Nordlinger, and Skocpol) comes at a time in the field of comparative politics when there is a desire to study the embodiment of the political as a separate and independent entity from the influence of the societal environment (see Evans, Rueschemeyer, Skocpol, 1985). The state as an analytical concept provides the framework in which "one" studies the political aspect of a given country independently from the societal environment (hence there is a strong concern for the autonomy of the state as an actor). The "return of the state" approach is a reaction to the notion that the study of politics is concerned with everything that influences political decisions, up to and including toilet behaviour, and suggests some phenomena are more central than others (see Evans, Rueschemeyer, Skocpol, 1985). 
The advocates of the "return to the state" argue that the study of political activity must be centred around that which makes the political decisions (i.e.; the institutions, government). Thus the study of the "state" is interesting, as Skocpol notes, because "the real dynamics of political life are found when social scientists are willing to look at societies and their economies, sites of the processes or structures" (Evans, Rueschemeyer, Skocpol 1985 , p. 19-20). The notion of the state depends upon an attempt to transcend the distinction between "government" and "civil-society". Skocpol notes, this attempt at transcending the above distinction ("government" and "society") is made because "government is not considered an independent actor" (Evans, Rueschemeyer, Skocpol 1985, p. 19-20). She, quoting Alfred Stephen, points out that the state must be considered as more than the government (Evans, Rueschemeyer, Skocpol 1985, p. 20). It is the continuous administrative, legal, bureaucratic, and coercive system that attempts not only to structure relationships between civil society and public authority, but it is also able to structure many crucial relationships within civil society as well. Here is where the advocates for the "return to the state" insist that it (the state) has to be an autonomous actor that can act independently from societal inputs (Evans, Rueschemeyer, Skocpol 1985, p. 20-22).

A problem arises in the "state" approach to politics, because the history of the state as a political concept is problematic. The term "state" itself comes first in use by Machiavelli, and later the term "state" was associated with the power of the sovereign (monarchs, princes, who held their realms by physical force). As democracies tended to prevail, the term fell into disrepute, as it was unfortunately perceived as being autocratic and undemocratic. Now, it is true that Hobbes and then later Rousseau found a way - via the social contact formulation - to harmonise the concept of the state with rule of the people. This popular sovereignty solution was later co-opted by the nation-state view, which argued that the ethnic nation was the frame out of which the modern state reached its perfection (see Manent 2006, $2007 \& 2010$ ). The problem with this is that the concept of the state is distinct from the concept of the nation by the fact that the state is a product of the will, whereas the nation arises out of the ethnic, linguistic and cultural frame that gives shape to a given people or nation.

It is in Max Weber that we find a "modern" attempt to define what the "state" is conceptually. Weber defined "the state" as "the monopoly of the legitimate use of physical force within a given territory." The key qualifier is the word "legitimate". For Weber, legitimacy is achieved through tradition, a popular charismatic man or group, or constitutionally (a legalistic interpretation). However, Weber argues that we don't understand a state by its "goals" but by its "means". Simply put, we understand what states are by their "means" rather than their "ends". This is Weber's attempt to de-ontologicalise the "state" from the understanding that Hegel provided in his Philosophy of Right in the mid-nineteenth century. The "myth of the state", developed from a Hegelian ontological argument, was the reason for the abandoning of the "state" concept by political scientists after the Second World War, because it was too closely associated with fascism (see Manent 1994b, 2006).

The "state" approach does have other serious problems. The least of them is the personification of the state by its advocates - such as Skocpol, Nettl, and Nordlingler. They give the state "a life on its own," by attributing the actions of political actors to the state itself. What is created is what I call the "non-ontological but quasi-re-ontologicalised" 
view of the state. Those authors, by saying "the state does this" and "the state does that," present the image that the "state" has an existence unto itself (that is akin to a human being) - hence leading to the validity of the charge that Lasswell and the hard core behaviouralists such as Dahl and Almond still make, against treating an inanimate thing as an autonomous being (Almond, 1988; Dahl, 1964). However, Skocpol et al., do not give "the state" a metaphysical grounding as Hegel does (hence they try to be true to Weber's notion that the state is to be defined by "means" and not "goals") but they still talk about it like Hegel does, so the implications of "goals" are pregnant in their discussions about the state (Evans, Rueschemeyer, Skocpol 1985, p. 107-168, 347-365).

Another more serious problem, from the political science aspect, is the fostering of the problem that critics of comparative politics have been complaining about, namely the imprecise use of terminology. This ambiguity of the term "state" just reinforces the lack of precision and inconstancy in the terminology that critics of comparative politics always argue against. In his review of the "return to the study of the state", Gabriel Almond is right on target when he notes that the concept of the "state" was always criticised by political theorists as a "class of objects" that cannot be "identified exactly" (Almond, 1988, p. 854-855). Almond notes that, although some scholars, while advocating the return of the "state", do "not effectively deal with the political theorists uneasiness about the ambiguity of the term" (Almond, 1988, p. 856). Then they go on and discuss the state as though the meaning of the term is self-evident. In the literature concerning "the return to the state", the "state" is used in a multiplicity of ways, one used the term one way, while another used the term in a different way (Almond, 1988, p. 855-859).

These criticisms of the "state" approach seem to have a great deal of validity. Those criticisms make one wonder about the value of the state approach to comparative politics. The weaknesses of the state approach seem to reinforce the view of comparative politics as being in a fundamental state of crisis. The more general conceptual framework that systems analysis employs promotes a comparative method to the examination of the politics of various countries. The generalisations that the "systems" approach provide develop into a larger scale "theory of political systems", which will be not only descriptive but also predictive and explanatory, thus overcoming the present limitations in Easton's systems approach.

\section{Revisiting Regime Analysis}

The current return to regime analysis - as the current literature in the area labels it - arises from the context of the return of the state or the "Bringing the State Back In" scholarship that came to the fore in comparative politics scholarship in the mid- to late 1980s and early 1990s, led by voices (such as Theda Skocpol and Charles Tilly) influenced by the Tocquevillian trend that was occurring in sociology in the same period. Finer holds that the historical state-centric approach he defended, while he was criticising the behaviouralists back in the 1960s, was proof he was riding the wave of the late 1980s, 1990s future (Finer, 1997). Yet if one looks at how political regimes are usually understood by the great variety of comparative political scientists, one notices that although they claim they are using the state-based models championed by Skocpol and others, 
when one looks more closely one notices that what is being seen as the structure of the political regime is either a framework of ideologies or a simplified framework which assumes political forms that arise from certain ideological assumptions (see Siaroff, 2009). The turn to the regime question in the study of states arose to avoid the problem of anthropomorphising that happens too commonly when dealing with the state as a holistic concept, something that the original behaviouralist scholars pointed to in justifying their abandoning of the state as a useful instrument of analysis of political behaviour.

But when we look at much of the regime analysis of those who came to champion the "Return of the State", all too often they employed many of the same overly democratic and pluralistic assumptions one found in Dahl's political model. One can clearly see this if one looks at Charles Tilly's work, especially his 2006 work Regimes and Repertories where his twofold regime model, following his review of the regime models of Aristotle, Dahl and Finer, echoes far more the structure of Dahl rather than that of Aristotle's use of regime. Yet, unlike Tilly, Dahl never uses the term regime, rather he prefers to use the term polity (see Dahl, 1964, 1956, 1971 and 1982). Tilly prefers to ignore such things and opts to use "regime" and puts Dahl's model as a regime schema system. Thus Tilly presents Dahl's model as a model with two clear categories -liberalisation or public contestation, and inclusiveness or the right to participate (Tilly, 2006, p. 23). So when one looks at Tilly's model, he presents a different yet similar set of two categories - governmental capacity and democracy. We clearly see that the regime model employed by Tilly has an explicit built in bias of 'democracy' which no-longer is to be considered a form of regime, but rather as a universal human political form that all human communities should strive to achieve.

Tilly charges that Finer's model follows that of Aristotle and is unlike that of Dahl, and thus it is unable to measure or follow relationships among regime types (Tilly, 2006, p. 15). I would argue that Tilly might be correct about this limitation to Finer's regime model, but as I will show this criticism does not hold true to Aristotle, and what distinguishes Finer's modelling from Aristotle's is that there is a clear interconnection between what shapes a regime type and how that regime transitions from one type to another, and variations within type - what Tilly calls forces of contention.

Yet with all these issues with Tilly mentioned, he nevertheless offers us a very good point for a turn to the main point of this paper, that a return to Aristotle's regime science would be a vast improvement to help us understand the true nature of regimes and thereby avoid the pitfalls of bias that reveal themselves in the regime models by Tilly and others. Tilly explicitly points to Aristotle's teaching about the regime (or as Tilly calls them - regimes) as being much more complex than what is usually assumed by contemporary scholars of comparative political systems and social change. Tilly, in summing up what he finds in Aristotle's treatment of regime, says the following:

Without developing his observations at length, Aristotle clearly saw different sorts of regimes as having their own characteristic forms of contention, and changes of regimes as resulting largely from political contention. In contrasting regimes, different ruling coalitions pursued distinct strategies of rule, which altered the incentives and capacities of various constituted groups within the state to defend or advance their own interest by acting collectively. Aristotle explained political struggles of his day by combining the perspectives of ra- 
tionalists and structuralists, millennia before anyone used those labels (Tilly, 2006, p. 10).

Yet even after saying what he did about Aristotle, as we clearly noted earlier, if one looks at the formal model he ultimately relies on to explain varieties of regime forms, he owes much more Robert Dahl than to Aristotle. We must ask why Tilly, who clearly relies on Aristotle's regime model as being interesting, and telling about issues of contestation, finally decides to use Dahl's model instead (Tilly, 2006, p. 25-29).

\section{The Differences between the State-based "Regime" Model and Aristotle's Politeia}

Now we must admit that there is a significant difference between how the regime (politeia) operated to give form and variety to the polis (in Latin the civitas), or the political community and the working of the modern state. The structure of the political community (either understood as polis or the civitas, or the political form before the emergence of the modern state in the $16^{\text {th }}$ century) was composed of communities of household networks that joined together for the purpose of achieving some sense of common advantage, which was understood as allowing all members of the community to live well or in a beautiful (kalos) manner, which allows the human being in that community to achieve their eudemonia, or fulfilling their capacity to live fully as a human being.

Now this common advantage and living beautifully that the political community allowed for is not something divorced from a sense of shared utility, because Aristotle makes rather clear in the Politics that living (or being able to live per se) is a necessary and essential precondition in order to live well. Thus in Aristotle's treatment of regimes (politeia) we find a concept that allows us to understand the nature and working of human political community in a way that allows us to see, in a generally undistorted manner, how the fundamentally social and political nature of human beings manifests itself.

\section{The Return to Aristotle's Concept of Politeia as the Basis of a Model for Regime Analysis}

The issue of the regime (politeia) is fundamentally tied to the concept of the political community as being a whole composed of parts. Now the fundamental part of the political community is held to be the household. But even if we take households as the basic unit of composition, there remain various types of households, not to mention associations of households. To say that the political community is an association of households is to beg the question of what that is composed of.

Book 3 teaches the reader that the regime is the fundamental ordering of the political community, in terms of the ordering of the who and how governs, as well as the way in which they govern and the ends or goals to which their governing strive to obtain. The teaching about the regime is that it will reflect the authoritative part of the political community, its ruling part (politeuma). But this governing body/ruling part (politeuma) is none the less a part of the whole. Contra the teaching of Hobbes and the modern teaching 
that follows from his understanding of government representing from the whole politic body as such, and not merely a ruling part, Aristotle teaches about the nature of political rule that it is a part of the political community that acts on behalf of the whole (either for its own sake or for the common benefit). Thus, the differences of regimes not only reflect different understandings of who should rule and why, but also the competing understandings of what is good per se (both in terms of self-interest and the interests of the community per se).

The teaching of the practical books of the Politics suggest that the very character of the regime will echo the character and make-up of the different parts that rule or have authority within a given political community. Thus to understand what part will rule within a given political community, one must know what are the various parts within it. Here is the reason for the turn in Politics 4.3 from the general types of regimes that one saw earlier in Politics 3.7, to an account of the parts of the polis/political community.

Aristotle notes in Politics 4.3 that one of the generic divisions of the parts of any given political community rests between the rich, the poor and the middling sort. Yet although he mentions the middling sort, he still notes that the division/distinction tends to remain between the rich and the poor. And that this tension between these two poles seems to point towards two general trends in the variations of regime and in the nature of political rule per se. Aristotle speaks of the distinction between the rich and poor as akin to the different types of winds that govern the weather. These tension points between the rich and poor seem be the one of the key forces of contestation that shape the dynamic in which part of the political community/polis is the controlling part over the others.

Aside from the issue of rich and poor, we have to deal with the larger and smaller part of the community. Aristotle seems to suggest that the question of number and size of the parts is as important to the issue of contestation for control and the shape of how that control will be exercised as the mere issue of comparative wealth or poverty. This is to say that any given political community will contain certain associations of parts (or groups) and those groups will vary in size and make-up, and will also vary in regards to what function they play within the given community. The given make-up of the different parts, and who does what and has what role within a given political community will have a very significant impact in how to understand the character of the regime.

In the last part of Politics 4.3, we not only move away from both the tension between the rich and the poor and that of the many and the few (which are all too often seen to be the same, but really are not), and now turn to the question of the ways of life that arise in a given political community. By the way of life, we mean to say the way of securing one's life, one's sustenance - what we would call today economics. The various ways of life deal with the differing means of production and producing the needs for the political community. We must recall for a political community to be a political community, it must not only share a common life and common identity but also be what Aristotle called self-sufficient, which means having the basic ability to act as a common political unit, and one of the means to do that is having the resource capacity (monetary, material, or human) to do so. Lacking such resource capacity, becoming an autonomous political community is highly unlikely.

Even if we say there has been much development of the question of lifestyle and economy since Aristotle's days, Aristotle's basic formation of ways of life between the forces of agriculture (both land and care and use of animals for meeting human needs), those 
who labour physically (referred to as the vulgar sort), and those who engage in commerce or trade (which would also include what today we call the service and finance sectors) remains as true today as it was in his time. He then connects the issue of different ways of life to the different parts of the community and the interaction of the two factors together, and the question of which part ultimately controls and rules in a community is that which ultimately shapes the way the regime of that given political community will present what way of life is held to be best and most authoritative way of life for that community.

From the presentation of regime forms and how those forms emerge that we found in Politics 4.3, we turn to chapters 4 through 10 where we have the presentation of various regime types and their different variations that occur within each particular type. We see the different types of democracies (in 4.4), oligarchies (in 4.5 [and in 4.6 a cross comparison between oligarchies and democracy]), aristocracies (in 4.8 ) and the regime that is called a regime (in 4.8 and 4.9 ) and then finally tyranny (4.10). From the presentation of the variety and sub-variety of regime, we then have a brief three chapter discussion of the question of what is the best type of regime practically (4.11) and then what type of regime suits what type of political community (4.12-13). These three chapters offer us an example of the comparative benefits and utility of each type of regime for each type of political community/city. We come to see the role of circumstance and the variety of make-up of given particular sets of givens that a political community/polis possesses and how it impacts the differing levels of advantage or disadvantage each different regime type would have in those conditions.

From the question of what regime type is best for what type of city/political community, we turn to a detailed discussion of political institutions per se (4.14-16). Here we have Aristotle's famous presentation of why political rule for the sake of effectiveness is divided into the classic three parts of rule - deliberation/deciding (4.14), the offices of implementing what has been decided (i.e., the various 'offices' of the given political community) (4.15), and the adjudicating or judging part of the political community (4.16). This is to become later in the history of political thought the classic three powers of government - legislative, executive and judicial, but for Aristotle what is talked about is not powers, but functions, and the treatment here suggests that function matters more in understanding how these institutions really work. In this discussion of institutions, we see how institutions themselves evolve and change in regard to function, and how that change impacts how regimes can and do change from one form (or sub-form) to another.

From the discussion of political institutions in the last three chapters of Politics 4 , we turn to the discussion of regime change and the question of how to preserve regimes in Politics 5. Throughout Book 5 we see a very detailed and complex account of how regimes change and can be preserved. And we see that Aristotle not only gives accounts of how to preserve the commonly viewed good regimes, but also the commonly held defective regimes as well (including, shockingly, tyranny in 5.10-11). At the end of Book 5, Aristotle takes on Plato's account of regime change as presented in the Republic. In taking on Plato's account of regime change, Aristotle criticises the view that there is only a single cycle of regime change. Rather, Aristotle makes the case that regime change varies greatly and the forces of change can be so subtle and so different that in different circumstances and with different conditions the direction of regime change can vary significantly, and that there is generally no one fixed cycle of revolution or regime change that is predetermined by the character or any given regime type. This is to say that any re- 
gime could change not only in terms of the variety of sub-types within the regime (in both directions within the subtypes) but also among general regime types. It is not so that aristocracy can only turn to oligarchy as Plato's account suggests, but it could also turn to democracy or tyranny. Likewise with the other regime types. This position against Plato's teaching could also be turned to the teaching of others who hold a similar predetermined cycle of political change, from Hegel to Marx (or even Nietzsche), and those who follow them in their dialectic model for political change, be it either progressive or regressive.

From the examination of regime change in Book 5, we have a re-examination of regimes and their forms in Politics 6 . At the start of Book 6 we have a return to a discussion of political institutions. But this discussion of political institutions adds what was learnt from the process of political change to what we learnt from Book 5, adding how different institutions and what role they have will vary from regime to regime. Here we get a more complex presentation of how the way institutions work and the role they have in a given city over time will change and be shaped by the given regime the city/political community has at any given time. The fact that regimes will shape the way institutions work recasts the discussion of Politics 4.14-16 in a new light, one which, like the discussion of how in Politics 3.14-16, we come to see how the law is relative to the type of regime. Hence the given set of institutions will vary, and what role they will have in any given type political community will be shaped by the regime. So any discussion of political institutions that does not address the question of regime is defective and as such distorts one's understanding of how institutions affect political action as well as the political behaviour of actors.

This clearly would have a big impact on various current discussions of political institutions that are now arising in contemporary political science from the dominance of game theory and rational choice in the study of political science. But even those who bemoan the pathologies of rational choice are blind to the regime question and failed to learn from Aristotle that the limits of rational choice are to be found in the way actors work within a given set of structures/rules that any given regime presents, but the rational choice model falls apart when it has to explain how we move from one set of rules to another, this is to say, how regime change occurs. Here Aristotle's account offers a very useful correction to those scholars of the rational choice approach.

From the re-examination of political institutions in 6.1, we turn to an account of the varieties of democracies and how they are established (Politics 6.2-5). Here Aristotle not only goes over ground that he went over in Politics 4.5 but he goes into more detail, dealing with the general character of democratic rule (6.2), the character of the principle of equality works within democratic rule (6.3), the varieties of democracy (6.4) and the ways democracies can be preserved (6.5).

From democracy, Aristotle turns to oligarchy. In the next two chapters Aristotle discusses the varieties of oligarchies and how they are established. The interesting point here in 6.8 is that the discussion of preserving oligarchies is left silent, and what is discussed is their establishment or creation. This suggests that perhaps any discussion of the issue of change in oligarchies that arose in Book 5 cannot be averted, or Aristotle is unwilling to make a clear case to how to avert them. Now this fact must be contrasted to what is clearly done in 6.5 and the difference in this question of perseverance perhaps suggests the preferring of one regime type over another. The fact that no other regimes than democracy and oligarchy are discussed in Book 6 is also a clue about how we should understand 
the opening of Politics 4 and the discussion of fundamental regime types. The hint in Politics 4.3 that there are commonly held to be two types of regimes - democracy and oligarchy - seems to be upheld in the more detailed discussion of regime types in Politics 6 . And the fact that Politics 6 ends with a chapter on another account of executive institutions, which Aristotle calls 'the offices' (6.8), seems to have the whole body of Book 6 framed by the question of political institutions.

If one looks closely at this last account of 'the offices,' we see it differs significantly from the account in Book 4.15. The account in 6.8 looks at the question of which offices are not only the most kalon (good, fine, beautiful) for a city, but the most necessary as well. Aristotle makes the case that the given size of the city will determine the number and variety of offices it will require and their relative beautiful/noble/good ordering. That smaller cities/political communities will need fewer officers than larger ones is not a shocking point, but then Aristotle moves on from the question of number to the question of type, and the rest of the chapter deals with an account of the given types of offices one would need in a well balanced political community.

On one level, the list of offices that we find in 6.8 suggests an ordering and character of those offices of a city that is beautifully ordered, which is the best political community, the political community whose regime is the best. Now, given that the next two books in the traditional ordering of the Politics deal with the best regime and the question of education for that regime, this discussion of the most proper ordering of offices suggests a preparation for the discussion of the best regime per se. Yet, on the other hand, the question of the best ordering also has an impact on the question of what is best in the realms of political practice as well. Given the discussion here is not about theoria but praxis, the apparent general character of the 6.8 discussion of the order of the offices perhaps point to a given regime and a given set of conditions for that regime to exist. The only time we get a given setting and place for any example of an office being discussed in 6.8 is somewhere in the middle, where in reference to a distinction between an office which guards prisoners and that office which is "the office that takes actions" the example of the "so-called Eleven" of Athens is given (6.8.1322a20). That Athens is the only political community that is named in this chapter perhaps should make us look more closely at this account and accounts of Athenian offices in general, perhaps this is what is intended by this chapter.

Regardless of the fact, no other specific example from any given political community begs us to question the practicality of the discussion of offices found in 6.8. It gives too much the hint of what contemporary political scientists would call normative. But is this the case? Does not this account seem to arouse in the reader more questions than answers? And in doing this, is not Aristotle getting us to re-read what was said, and getting the reader to start thinking about what was said, and to work through the problems that arise by what was presented?

\section{Conclusions}

When we again return to the main argument that this paper started with, the usefulness and benefit to contemporary comparative politics in returning to the origins of comparative politics as found in Aristotle's regime science in his Politics, or when looking as we 
did at the various contemporary approaches to recapture what Aristotle understood as a regime, but what modern proponents call a regime or polity, we see that Aristotle's approach possesses more characteristics of objectivity and specificity than that which contemporary comparative political scientists say they aspire to. And if we compare Aristotle's typology of regime analysis to the various models of regime analysis commonly used by contemporary students of comparative politics, we clearly see that Aristotle's regime model has far fewer hidden, or even explicit normative biases in it than those commonly found when reviewing comparative politics literature.

Given this, a strong case could be made that students of comparative political science (not only in undergraduate studies, but graduate and doctoral studies) should be carefully turning to and studying Aristotle's Politics in their scope and methods courses. The importance of Aristotle's Politics for students of comparative politics was explicitly stated by most of the founding generation of behavioural comparative politics - Almond, Nye, Verba, Dahl, and Huntington. Yet, if one surveyed the US major departments of political science (offering doctoral degrees) with a strong emphasis on comparative politics, one would see that little or no effort is made to have students confront the lessons of Aristotle's Politics. The number of comparative politics graduate programs with a focus on comparison that require students to seriously read and learn from what Aristotle could teach them in the Politics could easily be counted on the fingers of both hands.

The usual argument is that students would be exposed to it in undergraduate political theory. But such courses are all too often overview courses, or courses that focus on aspects of teachings that seek to address different concerns than what would interest those focusing on comparative politics. The vast majority of US $\mathrm{PhD}$ programs in comparative politics do not require doctoral students to take graduate level political theory reading courses that would explicitly expose their students to the ideas of the history of political thought. And even if students in such doctoral programs wanted to be exposed to a graduate course on Aristotle's Politics offered by those departments' political theory sections, a close look at the vast majority of US doctoral programs in political science shows that very few of them have such a course listed in their general offerings in any regular cycle.

This fact - the absence of exposure to not only Aristotle's Politics but the other most important figures of political thought in the graduate education of most future students of comparative politics - is commonly bemoaned by the likes of Almond, Dahl, Huntington, Schmitter, Przeworski and even Robert Bates of rational choice fame! Those leading figures of comparative politics often openly complained consistently in the decade bridging the $20^{\text {th }}$ and $21^{\text {st }}$ century about the lack of exposure that most students of comparative politics had to the great political thinkers of the past (see Munck, Snyder 2007). Yet, for all the talk, there has been no action taken to alter the situation in comparative graduate programs. So we find once again that the emperors have no clothes on. The emperors (and here we mean the leading voices in comparative politics) in their hearts of hearts (or more correctly in their own self-understanding, if they are being really honest with themselves) know this as well.

\section{Bibliography}

Almond G. A., Powell Jr. G. B., Dalton R. J., Strom K. (2008), Comparative Politics Today: A World View, $9^{\text {th }}$ edition, Pearson, New York. 
Almond G. A. (1988), Return of the State, "The American Political Science Review", vol. 82, no. 3 (September), pp. 853-874.

Apter D. E. (1988), Rethinking Development, Sage Publications, Newbury Park-Beverly Hills.

Arendt H. (1958), The Human Condition, Doubleday, Garden City, N.Y.

Axelrod R. (1983), The Evolution of Cooperation, Harvard University Press, Cambridge.

Bates C. A. Jr. (2003), Aristotle's Best Regime, LSU Press, Baton Rouge.

Bates R. (1987), Agrarian Politics, in: Understanding Political Development, eds. Weiner, Huntington, Brown and Co., Boston-Little, pp. 160-195.

Bloom A. (1987). The Closing of the American Mind, Simon and Schuster, New York.

Bodin J. (1993), Les Six livres de la République, Livre de Poche, Paris.

Codevilla A. M. (2009), The Character of Nations: How Politics Makes and Breaks Prosperity, Family and Civility, Revised Edition, Basic Books, New York.

Dahl R. (1964), Modern Political Analysis, Prentice Hall, Englewood Cliffs.

Dahl R. (1956), A Preface to Democratic Theory, University of Chicago Press, Chicago.

Dahl R. (1971), Polarchy: Participation and Opposition, Yale University Press, New Haven.

Dahl R. (1982), Dilemmas of Pluralist Democracy, New Haven, Yale University Press.

de Alvarez L. P. S. (1989), Niccolo Machiavelli: The Prince, Waveland Press, Prospect Heights, Ill.

Dietz M. (2012), Between Polis and Empire: Aristotle's Politics, "American Political Science Review", vol. 106, issue 02 (May 2012), pp. 275-293.

Easton D. (1953), The Political System. An Inquiry into the State of Political Science, Knopf, New York.

Evans P. B., Rueschemeyer D., Skocpol T. (1985), Bringing the State Back in, Cambridge University Press, Cambridge.

Ewbank M. B. (2005), Politeia as Focal Reference in Aristotles's Taxonomy of Regimes, "The Review of Metaphysics", vol. 53, no. 3.

Farrar C. (1988), The Origins of Democratic Thinking, Cambridge University Press, Cambridge.

Finer S. E. (1997), The History of Government from the Earliest Times, 3 volumes, Oxford University Press, Oxford.

Fukuyama F. (1992), The End of History and the Last Man, The Free Press, New York.

Fukuyama F. (2011) The Origins of Political Order, Farrar, Straus and Giroux, New York.

Geertz C. (1965), The Impact of the Concept of Culture on the Concept of Man, in: New Views of the Nature of Man, ed. J. R. Platt, University of Chicago Press, Chicago.

Geertz C. (1973), Interpretation of Cultures, Basic Books, New York.

Goldsmith T. H. (1991), The Biological Roots of Human Nature: Forging Links between Evolution and Behavior, Oxford University Press, Oxford

Hansen M. H. (1993), Aristotle's Alternative to the Sixfold Model of Constitutions, in: Aristote et Ate'nes = Aristotle and Athens, Seminarie d'histore ancienn, Fribourge (Suisse).

Hansen M. H. (1994), Polis, Politeuma and Politeia: A Note on Arist. Pol. 1278b6-14, in: From political architecture to Stephanus Byzantius: sources for the ancient Greek polis, F. Steiner, Stuttgart.

Hardt M., Negri A. (2000), Empire, Harvard University Press, Cambridge.

Hintze O. (1975), The Preconditions of Representative Government in the Context of World History, in: The Historical Essays of Otto Hintze, ed. F. Gilbert, Oxford University Press, New York.

Higgot R. A. (1983), Political Development Theory, Croom Helm, London.

Hobbes T. (1991[1651]), Leviathan, ed. R. Tuck, Cambridge University Press, Cambridge.

Huntington S. (1987), The Goals of Development, in: Understanding Political Development, eds. Huntington, Myer, Little, Brown, Boston. 
Huntington S. (1981), American Politics: The Promise of Disharmony, Harvard University Press. Cambridge.

Huntington S. (1968[2006]), Political Order and Changing Societies, Yale University Press, New Haven.

Keyt D., Miller F. (1991), eds., A Companion to Aristotle's "Politics", Blackwell, Oxford.

Keyt D. (1999), Aristotle's Politics Book V and VI, Claredon Press, Oxford.

Keyt D. (1987), Three Fundamental Theorems in Aristotle's Politics, Phronesis 32, pp. 54-79.

Lilla M. ed. (1994), New French Thought: Political Philosophy, Princeton University Press, Princeton.

Lord C. (1984), Aristotle: The Politics, University of Chicago Press, Chicago.

Lord C. (1987), Aristotle, in: History of Political Philosophy, eds. L. Strauss, J. Cropsey, University of Chicago Press, Chicago, pp. 118-154.

Lord C. (2003), The Modern Prince: What Leaders Need to Know Now, Yale University Press, New Haven, $\mathrm{Ct}$.

Lord C. (2012), Proconsuls: Delegated Political-Military Leadership from Rome to America Today, Cambridge University Press, Cambridge.

Lowenthal A. (2009), Samuel P. Huntington 1927-2008, "New Perspectives Quarterly", vol. 26, no. 2.

Manent P. (1994a), An Intellectual History of Liberalism, Princeton University Press, Princeton.

Manent P. (1994b), The Modern State, Lilla, pp. 123-133.

Manent P. (1994c), The Contest for Command, Lilla, pp. 178-185.

Manent P. (2006), A World Beyond Politics: A Defense of the Nation-State, Princeton University Press. Princeton.

Manent P. (2007), Democracy Without Nations? The Fate of Self-Government in Europe, ISI Press. Wilmington DE.

Manent P. (2010), Les Metamorphose de la cite, Flammarion, Paris.

Mansfield Jr. H. C. (1983), On the Impersonality of the Modern State: A Comment on Machiavelli's Use of Stato, "American Political Science Review", 77, pp. 849-857.

Mansfield Jr. H. C. (1989), Taming the Prince, The Free Press, New York.

Mansfield Jr. H. C. (1995), Self-Interest Rightly Understood, "Political Theory", vol. 21, no. 1 (Feburary), pp. 48-66.

Masters R. D. (1989a), The Nature of Politics, Yale University Press, New Haven.

Masters R. D. (1989b), Gradualism and Discontinuous Change in Evolutionary Theory and Politica; Philosophy, "Journal of Social and Biological Structures", vol. 12, pp. 281-301.

Masters R. D. (1991), Naturalistic Approaches to the Concept of Justice, "American Behavioral Scientist", 34,3 (January/February), pp. 289-313.

Masters R. D. (1993), Beyond Relativism: Science and Human Values, University of New England Press, Hanover, N. H.

Meier Ch (1990), The Greek Discovery of Politics, trans. D. McLintock, Harvard University Press. Cambridge.

Munck G. L., Snyder R. (2007), Passion, Craft, and Method in Comparative Politics, Johns Hopkins University Press, Baltimore, MD

Nichols M. P. (1991), Citizens and Statesmen, Rowman and Littlefield, Savage, Maryland.

Nussbaum M. (1992), Human Functioning and Social Justice: In Defense of Aristotelian Essentialism, "Political Theory", 20, 3 (May), pp. 202-246.

Nussbaum M., Sen A. (1993), The Quality of Life, The Clarendon Press, Oxford.

Popper K. (1945), The Enemies of the Open Society, 2 vols., Routledge and Kegan and Paul, London. 
Palmer M. (1989), Dilemmas of Political Development, F. E. Peacock, Itasca, Illinois.

Pocock J. G. A., (1975), The Machiavellian Moment, Princeton University Press, Princeton.

Pompkin S. (1979), The Rational Peasant, University of California Press, Berkeley.

Pye L., Verba S. (1965), Political Culture and Political Development, Princeton University Press, Princeton.

Ricci D. M. (1984), The Tragedy of Political Science: Politics, Scholarship and Democracy, Yale University Press, New Haven, Ct.

Robinson R. (1962), Aristotle's Politics Book III and IV, Clarendon Press, Oxford.

Rousseau J.-J. (1978), On the Social Contract, ed. R. Masters, trans. J. Masters, St. Martins Press, New York.

Rousseau J.-J. (1964), The First and Second Discourses by Jean-Jacques Rousseau, translated by R. D. Masters, J. R. Masters, St. Martin's Press, New York.

Schmitt C. (1976), The Concept of the Political, trans. G. Schwab, Rutgers University Press, New Brunswick.

Scott J. (1976), The Moral Economy of The Peasant, Yale University Press, New Haven.

Siaroff A. (2009), Comparing Political Regimes: A Thematic Introduction to Comparative Politics, $2^{\text {nd }}$ edition, University of Toronto Press, Toronto, Ontario.

Simpson P. (1997), The Politics of Aristotle-Translation and Introduction, University of North Carolina Press, Chapel Hill.

Tilly Ch. (2006), Regimes and Repertoires, University of Chicago Press, Chicago.

Tocqueville A. de (2000) Democracy in America, trans. and edited by H. C. Mansfield Jr, D. Winthrop, University of Chicago Press, Chicago.

Wallerstein I. (1990), The States in the Institutional Vortex of the Capitalist World Economy, "International Social Science Journal", 32, 4, pp. 743-751.

Wiarda H. (1985), Toward a Nonethnocentric Theory of Development, in: New Directions in Comparative Politics, Westview Press, Boulder.

Wiarda H. (1991), Concept and Models in Comparative Politics, in: Comparative Political Dynamics, eds. D. A. Rustow, K. A. Erickson, Harper Collins, New York.

\section{Wspólezesna polityka porównaweza i odrodzenie analizy reżimu a odrodzenie arystotelesowskiej nauki o reżimie}

\section{Streszczenie}

W artykule zasugerowano, że porównanie różnych modeli behawioralnych i podejścia post-behawioralnego (rozumianego przede wszystkim jako „powrót państwa” i pojęcie reżimu politycznego, będace wynikiem tego powrotu) $\mathrm{w}$ celu porównania systemów politycznych prowadzi do wniosku, że arystotelesowska nauka o reżimie jest nadrzędnym punktem odniesienia dla rozmaitych modeli większości koncepcji reżimu opracowanych w ramach wspólczesnej politologii porównawczej. Badając wszystkie te próby zmierzające do odrodzenia koncepcji reżimu jako instrumentu analizy zachowań politycznych człowieka dostrzega się, że podejście przyjęte przez Arystotelesa pozwala na celniejsze i dokladniejsze przedstawienie zachowań politycznych występujących w strukturze określonych społeczności politycznych kształtowanych według danego reżimu.

Słowa kluczowe: polityka Arystotelesa, polityka porównawcza, reżim(y), system(y) polityczny/e, behawioralizm 